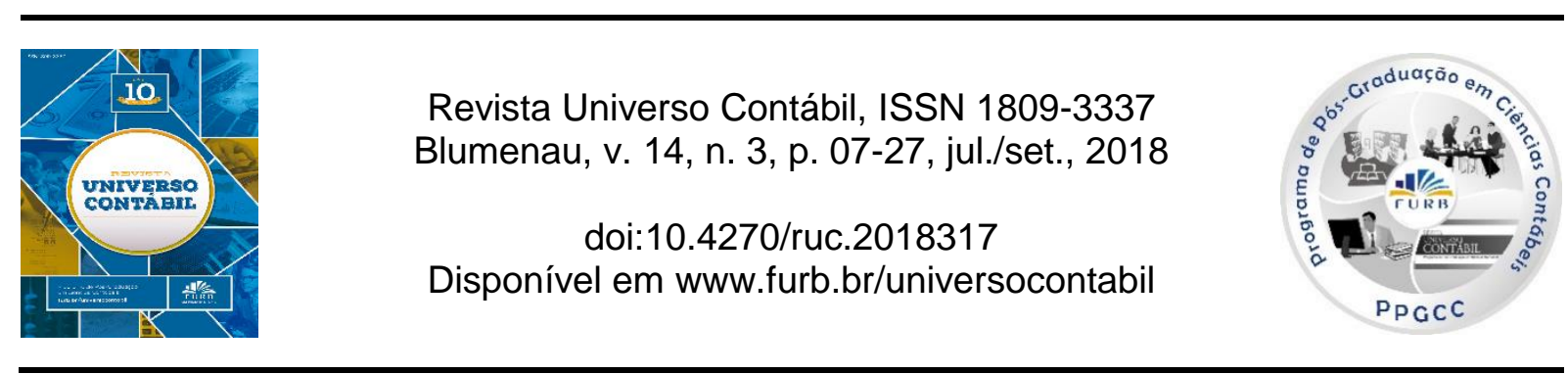

\title{
SUSTENTABILIDADE DA DÍVIDA PÚBLICA: UMA ANÁLISE DE CURTO E LONGO PRAZO APLICADA AOS MUNICÍPIOS AGREGADOS'
}

\section{SUSTAINABILITY OF PUBLIC DEBT: AN SHORT AND LONG TERM ANALYSIS APPLIED TO AGGREGATE MUNICIPALITIES}

\section{SUSTENTABILIDAD DE LA DEUDA PÚBLICA: UN ANÁLISIS A CORTO Y LARGO PLAZO APLICADO A LOS MUNICIPIOS AGREGADOS}

\begin{abstract}
Vanessa Rodrigues dos Santos Cardoso
Mestranda do Programa de Pós-Graduação em Ciências Contábeis da Universidade de Brasília Endereço: SGAN 603 Módulos I/J - Asa Norte CEP 70830-110 - Brasília - DF - Brasil E-mail: vanessarscardoso@hotmail.com Telefone: (61) 98636-4828

Daniel Azevedo Pansani Mestrando do Programa de Pós-Graduação em Ciências Contábeis da Universidade de Brasília Endereço: SGAN 601 Módulo V - SERPRO Sede - Asa Norte CEP 70836-900 - Brasília - DF - Brasil E-mail: danielpansani@gmail.com Telefone: (61) 98162-0390

André Luiz Marques Serrano

Doutor em Economia pela Universidade de Brasília Professor do Programa de Pós-Graduação em Ciências Contábeis da Universidade de Brasília Endereço: UNB - Campus Universitário Darcy Ribeiro, FACE - sala B1 23/4 - Asa Norte CEP 70910-900 - Brasília - DF - Brasil E-mail: andrelms@unb.br Telefone: (61) 3107-0812

Marcelo Driemeyer Wilbert Doutor em Economia pela Universidade de Brasília Professor do Programa de Pós-Graduação em Ciências Contábeis da Universidade de Brasília Endereço: UNB - Campus Universitário Darcy Ribeiro, FACE - salas B1-B2 - Asa Norte CEP 70910-900 - Brasília - DF - Brasil E-mail: marcelodw@unb.br Telefone: (61) 3107-0812
\end{abstract}

\footnotetext{
${ }^{1}$ Artigo recebido em 17/08/2017. Revisado por pares em 05/10/2018. Reformulado em 28/01/2019. Recomendado para publicação em 19/03/2019 por Marcia Zanievicz Silva. Publicado em 30/03/2019. Organização responsável pelo periódico: FURB.
} 


\section{RESUMO}

A recente piora das condições macroeconômicas brasileiras, com reflexos no agravamento das finanças públicas nos três níveis de governo trazem à tona preocupações com a sustentabilidade da dívida pública. As diversas repactuações da dívida municipal realizadas desde 1987, bem como a promulgação da Lei de Responsabilidade Fiscal (LRF), que limitou despesas e endividamento, com vistas a estabelecer maior governança à Administração Pública, são exemplos de esforços do Governo Federal para conter a deterioração da situação fiscal dos entes subnacionais. Nesse sentido, espera-se que as dívidas contraídas por estes entes sejam sustentáveis. Dessa forma, este estudo objetiva analisar o comportamento da dívida pública municipal agregada quanto à sua sustentabilidade no período de 2002 a 2018. Utilizando séries de longo prazo, foram testadas estacionariedade e cointegração da dívida com o resultado primário, assim como a reação desse último às variações daquela. Os testes de curto prazo se basearam na proposta de Pasinetti (1998). Os resultados econométricos indicaram sustentabilidade para o período completo de 2002 a 2015. Entretanto, o teste de Pasinetti apontou persistência de insustentabilidade por quarenta e seis meses consecutivos iniciados em fevereiro de 2015 até novembro de 2018, havendo relação com a recessão econômica. Os achados indicam que as medidas de socorro implementadas pelo Governo Federal e a austeridade pretendida pela LRF não foram suficientes para manter a dívida pública dos municípios em patamar considerado sustentável nos períodos recentes.

Palavras-chave: Sustentabilidade; Dívida Pública Municipal; Política Fiscal.

\section{ABSTRACT}

The recent set back of Brazilian macroeconomic conditions, which affected the public finances at the three levels of government, raise concerns towards the sustainability of public debt. The several renegotiations of municipal debts that have been performed since 1987, as well as the enactment of the Fiscal Responsibility Law (FRL), which limited expenses and indebtedness, aiming at establishing greater governance of the Public Administration, are examples of efforts from the Federal Government to contain the deterioration of the fiscal situation of subnational entities. In this sense, the debts contracted by those entities are expected to be sustainable. Thus, this study aimed at identifying the existence of a sustainability condition for the aggregate municipal public debt, based on stationarity tests and cointegration of debt with the primary result, as well as by the reaction of the primary result to the variations of the debt. Month-bymonth verification, for the period from 2002 to 2018, was performed through the test proposed by Pasinetti (1998). The econometrical findings indicate sustainability for the whole period from 2002 to 2015. However, Pasinetti test showed the persistence of unsustainability for fortysix consecutive months, from February 2015 until November 2018, related to the economic recession. These findings indicate that the safety measures implemented by the Federal Government and the austerity intended by the FRL have not been enough to maintain municipal public debt at a sustainable level.

Keywords: Sustainability; Municipal Public Debt; Fiscal Policy.

\section{RESUMEN}

El reciente empeoramiento de las condiciones macroeconómicas brasileñas, con reflejos en la agravación de las finanzas públicas en los tres niveles de gobierno sacan a relucir preocupaciones con la sustentabilidad de la deuda pública. Las diversas renegociaciones de la deuda municipal realizadas desde 1987, así como la promulgación de la Ley de Responsabilidad Fiscal (LRF), que limitó gastos y endeudamiento, con vistas a establecer mayor gobernabilidad a la Administración Pública, son ejemplos de esfuerzos del Gobierno Federal para contener el deterioro de la situación fiscal de los entes subnacionales. En ese sentido, se espera que las 
deudas contraídas por estos entes sean sustentables. De esa forma, este estudio objetiva analizar el comportamiento de la deuda pública municipal agregada em cuanto a su sustentabilidad en el período de 2002 a 2018. Utilizando series a largo plazo, se probaron estacionariedad y cointegración de la deuda con el resultado primario, así como por la reacción de ese último a las variaciones de aquélla. Las pruebas a corto plazo se basaron en la propuesta por Pasinetti (1998). Los resultados econométricos indicaron sustentabilidad para el período completo de 2002 a 2015. Mientras, la prueba de Pasinetti apuntó persistencia de insustentabilidad por cuarenta y seis meses consecutivos iniciados en febrero de 2015 hasta noviembre de 2018, habiendo relación con la recesión económica. Los hallazgos indican que las medidas de auxilio implementadas por el Gobierno Federal y la austeridad pretendida por la LRF no fueron suficientes para mantener la deuda pública de los municipios en nivel considerado sostenible en los períodos recientes.

Palavras-chave: Sustentabilidad; Deuda Pública Municipal; Política Fiscal.

\section{INTRODUÇÃO}

A deterioração das finanças públicas dos municípios brasileiros tem se tornado tema frequente. $\mathrm{O}$ diagnóstico é comumente explicado por uma equação intuitiva e simples de entender: redução das receitas e concomitante manutenção ou aumento das despesas na administração pública. Tal condição, se não revertida ou controlada, resulta em insustentabilidade da situação fiscal no longo prazo.

Diversas medidas foram tomadas ao longo do tempo com vistas a controlar o endividamento dos municípios, como por exemplo, as renegociações permitidas pela Lei $\mathrm{n}^{\circ}$ 8.727/1993 e a própria Lei Complementar $n^{\circ}$ 101/2000 (Lei de Responsabilidade Fiscal - LRF) que, baseada nos conceitos de boas práticas de gestão do Fundo Monetário Internacional (FMI), impôs limites à gestão fiscal dos entes federados, com vistas a controlar os gastos e o endividamento, que é a proporção da dívida em relação às receitas arrecadadas ou Produto Interno Bruto (PIB) (ARAÚJO; SANTOS FILHO; GOMES, 2015).

Posteriormente, a Medida Provisória $n^{\circ}$ 2.185/2001 e mais recentemente, a Lei Complementar $\mathrm{n}^{\circ}$ 148/2014 objetivavam inserir algum controle de endividamento, mas também representaram um tipo de alívio ou afrouxamento fiscal, na medida em que permitiram a redução das obrigações dos municípios advindas de sua dívida.

A literatura aponta que a vigência da LRF pode ter provocado efeitos controversos nas finanças municipais. Se por um lado favoreceu a melhora de resultado primário como resultado de melhor gestão de despesas, especialmente as de pessoal e incentivou a contenção do crescimento da dívida de alguns municípios, por outro lado acabou por induzir municípios que antes não gastavam acima do limite estabelecido na Lei a aumentarem seus gastos até esse limite.

Além disso, a LRF pode não ter sido exitosa em conter potenciais efeitos de incentivos que outros mecanismos governamentais fornecem e que são contrários aos seus objetivos, como por exemplo, os repasses da União, por meio do Fundo de Participação dos Municípios (FPM), e dos Estados, em função dos repasses provenientes do Imposto de Circulação de Mercadorias (ICMS) (MASSARDI; ABRANTES, 2016; MORAIS; BONIFÁCIO, 2016) aos municípios e as medidas de afrouxamento fiscais citadas acima. Essas transferências são apontadas pela literatura, como incentivadoras de comportamentos ineficientes e até irresponsáveis em relação aos gastos e esforços de arrecadação (VELOSO, 2008; COSSIO, 1998, CARVALHO; DE OLIVEIRA; CARVALHO, 2009; NASCIMENTO, 2010).

Medidas de afrouxamento fiscal também podem fornecer incentivos perversos: havendo sinais de que em algum momento será possível receber recursos da União, conseguir perdão ou renegociação de dívida sem que seja necessário ajustar-se a um padrão limitador de gastos, o município pode responder ao incentivo na forma de comportamento ineficiente. 
As finanças públicas municipais também podem ser afetadas pela situação econômica do país. De acordo de acordo com o Comitê de Datação de Ciclos Econômicos (CODACE) da Fundação Getúlio Vargas, entre abril de 2014 e dezembro de 2016, o Brasil enfrentou período de recessão (FGV, 2015; 2017). Corroborando esses dados, o Banco Central do Brasil (2016) afirma que desde o início de 2015 a atividade econômica demostrou forte recuo, com consequente aumento do desemprego. Além disso, o país convivia com inflação persistente e elevada taxa de juros, embora em trajetória decrescente desde outubro de 2016.

Este cenário tende a impactar significativamente as contas públicas, em face da redução na arrecadação tributária e aumento ou mesmo manutenção de gastos predominantemente rígidos, como, por exemplo, gastos de pessoal. Sobre esses gastos, pesquisa realizada com 1.697 municípios revelou que ao menos $30 \%$ da amostra extrapolara o teto de gastos com pessoal até meados de 2016 e outros $29,6 \%$ estavam próximos de alcançar o limite imposto pela legislação vigente (CONFEDERAÇÃO NACIONAL DOS MUNICÍPIOS [CMN], 2016).

A deterioração observada no âmbito municipal é reflexo do que acontece no âmbito federal e estadual. Estudo do FMI sobre finanças públicas indicou que entre países emergentes e países de renda média, totalizando 40 nações, o Brasil apresentou um resultado nominal de 10,3\% do PIB em 2015, inferior à média de -4,4\% dos países comparados (FMI, 2016). De fato, no âmbito federal, considerando o período entre 2002 e novembro de 2018, a proporção das necessidades de financiamento do setor público nominais (NFSPn) sobre PIB saiu de 4,42\% em 2002, alcançando o mínimo de 1,3\% em outubro de 2008, e após forte crescimento iniciado em maio de 2014, atingiu o mais alto patamar em janeiro de 2016 (10,73\%). Em novembro de 2018 essa relação ainda não havia retornado à média do período, de 4,48\%, situando-se em $7,1 \%$.

Já no âmbito municipal, após recuo verificado nos primeiros anos de vigência da LRF, houve ao longo do tempo alternância de melhora e piora da relação NFSPn/PIB, com o pior índice alcançado em março de 2016 (0,29\%), porém retornando aos níveis abaixo da média de $0,16 \%$ a partir de janeiro de 2017.

O déficit primário nas contas municipais se traduz em aumento da dívida, o que, ocorrendo de forma recorrente não é sustentável no longo prazo. Por sustentabilidade, entendese a geração de receitas que possam cobrir as despesas primárias e os juros de forma que não permita o crescimento da dívida no longo prazo (HAMILTON; FLAVIN, 1986; SIMONASSI, 2007; COSTA, 2009). No curto prazo, a sustentabilidade pode ser medida por superávits primários maiores que a diferença entre a taxa de juros da dívida e o PIB multiplicado pela proporção da dívida sobre o PIB (PASINETTI, 1998).

Nesse contexto, apresenta-se o seguinte problema: no período de vigência da LRF, a dívida pública municipal atendeu às condições de sustentabilidade apontadas na literatura? Portanto, o objetivo da pesquisa é analisar o comportamento da dívida pública municipal agregada quanto à sua sustentabilidade no período de 2002 a 2018, por meio de indicadores de curto e longo prazo. Nesse intervalo, ocorreram dois fatos cujos efeitos são aparentemente contraditórios: o afrouxamento fiscal concedido pela Lei Complementar $n^{\circ} 148 / 2014$ e a recessão econômica que se instalou entre abril de 2014 e dezembro de 2016. Sendo assim, também procura-se identificar se há indícios de influência desses fatos sobre o desempenho da dívida municipal. Para tanto, utilizou-se os dados de dívida pública e superávit primário municipais disponibilizados pelo Banco Central do Brasil (BCB). Foram aplicados testes econométricos de estacionariedade e cointegração, que podem ser classificados como de longo prazo; e análise de comportamento do superávit em função do crescimento da economia e das taxas de juros, como propôs Pasinetti (1998), aplicados a janelas de curto prazo.

A pesquisa justifica-se por existir lacuna sobre o potencial da LRF como ferramenta de gestão fiscal quando existem outros fatores, de caráter macroeconômico ou político atuando, com potenciais efeitos sobre à sustentabilidade da dívida. Além disso, não é conhecido se 
indicadores de sustentabilidade da dívida pública de curto e de longo prazo conhecidos na literatura apontam diagnósticos convergentes e simultâneos. Ademais, os efeitos do afrouxamento fiscal ocorrido em 2014 e da recente recessão brasileira que durou onze trimestres sobre as finanças dos municípios ainda não foram amplamente investigados pela na academia.

O trabalho está assim organizado: além desta breve introdução, a segunda parte apresenta referencial teórico acerca da LRF, bem como apresenta conceitos teóricos sobre sustentabilidade da dívida pública. A terceira parte aborda a metodologia utilizada cujos resultados serão apresentados na quarta parte. Por fim, apresentam-se as considerações finais.

\section{REFERENCIAL TEÓRICO}

Os limites impostos pela LRF pretendiam garantir que o comportamento fiscal dos administradores públicos seguisse uma trajetória voltada à austeridade, mas medidas de repactuação e renegociação da dívida municipal e a recente recessão brasileira parecem emitir incentivos controversos. É nesse contexto que a teoria sobre os conceitos de sustentabilidade da dívida pública permite avaliar como se deu o desempenho dos municípios brasileiros, de forma agregada, nos períodos recentes. As subseções seguintes apresentam a discussão sobre esses aspectos.

\subsection{Lei de Responsabilidade Fiscal, afrouxamento fiscal e recessão}

Envelhecimento da população e recessão motivaram o início da discussão sobre sustentabilidade da dívida na maioria dos países industrializados nos anos 1990 (SIMONASSI, 2007).

No Brasil, o endividamento dos estados e municípios brasileiros é oriundo da crise externa do início da década de 1980 (PINTO et al., 2015). Nos anos seguintes, a preocupação com a dívida dos municípios foi refletida em diversos dispositivos. Já em 1987, a Lei no 7.614 autorizou a realização, em caráter extraordinário, de operações de crédito à conta e risco do Tesouro Nacional, aos Estados e Municípios, mediante suprimento específico adiantado pelo Banco Central do Brasil (BRASIL, 1987).

Por seu turno, a Constituição Federal de 1988 já definia a necessidade de uma lei que fixasse os princípios norteadores das finanças públicas, demonstrando que o endividamento público é uma questão central do governo. Porém, em 1989, a Lei $\mathrm{n}^{\circ} 7.976$ permitiu o refinanciamento pela União da dívida externa de responsabilidade dos Estados, do Distrito Federal e dos Municípios (BRASIL, 1989). No mesmo sentido, a Lei nº 8.727/1993 refinanciou e reescalonou o prazo de pagamento de dívidas de estados e municípios junto a empresas federais (BRASIL, 1993). Seus efeitos lograram êxito apenas até fevereiro de 1994, período em que a razão dívida líquida/PIB se manteve em $31 \%$.

Segundo Giambiagi e Além (2016), inspirada no caso de sucesso da Nova Zelândia, a LRF foi aprovada em 2000 e definiu como deveria ser o comportamento dos três níveis de governo com relação às finanças públicas. A LRF forneceu mais instrumentos de controle, com vistas à eficácia na política fiscal, colocando limites ao endividamento e à utilização da máquina pública para objetivos de cunho eleitoral por gestores públicos (ARAÚJO; SANTOS FILHO; GOMES, 2015). Resumidamente, a LRF fixou limites para despesas com pessoal e para dívida pública, determinando que fossem criadas metas fiscais trienais, possibilitando o planejamento e o controle de receitas e despesas, e não permitindo a criação de despesa continuada sem indicação de fonte ou sem redução das despesas já existentes, de modo a não comprometer orçamentos futuros (BRASIL, 2000).

Para Matias-Pereira (2012), a LRF representa um código de conduta para os administradores públicos de todo o país. Lopreato (2016) afirma que a LRF possibilitou a criação de regras de comportamento para os entes federativos, a fim de possibilitar maior 
previsão à situação fiscal. Pinto, Costa e Wilbert (2015) consideram que se a LRF propiciou ferramentas de gestão da dívida e, uma vez que esta é uma forma de governança, a lei, em si, seria um instrumento de governança no setor público cujo objetivo é o equilíbrio fiscal e controle do endividamento como contribuição para o crescimento estabilizado. O controle do endividamento, por sua vez, foi o principal motivo para a elaboração da LRF, de acordo com Nascimento e Debus (2002).

Gadelha (2011) demonstrou que a LRF impactou positivamente o comportamento fiscal dos municípios, melhorando o seu resultado primário. Jesus Macedo e Corbari (2009) verificaram que o desempenho da estrutura de capital entre 1996 e 2006 sugeriu maior efetividade na gestão da dívida e das fontes de capital dos municípios brasileiros. Linhares, Penna e Borges (2013) observaram que após a LRF, os municípios do Piauí reduziram seu endividamento entre 6,69\% e 7,92\%. Lima (2011), ao analisar o desempenho do nível da dívida dos grandes municípios brasileiros de 2000 a 2008, verificou que a LRF acentuou a eficácia no controle do endividamento.

Araújo, Santos Filho e Gomes (2013) apontaram que logo após a promulgação da Lei ocorreu redução de endividamento, mas isso não se sustentou no longo prazo. Mello e Dalchiavon (2012) sugeriram que a LRF contribuiu para controlar a dívida somente de alguns municípios, pois a maioria já cumpria os limites da Lei mesmo antes de sua vigência. Os achados de Costa (2008) corroboram com esse entendimento. Para o autor, a LRF objetivava controlar apenas os municípios mais endividados como São Paulo, por exemplo, que apresentava o mais alto endividamento no período da pesquisa (1999 a 2004). No mesmo sentido, Fioravante, Pinheiro e Vieira (2006) identificaram que a LRF fixara limites acima dos realizados pelos municípios, estimulando aumento dos gastos daqueles que gastavam menos que o teto, embora os que gastavam acima tenham se adequado.

Assim, embora represente avanços importantes, a LRF é criticada por Santolin, Jayme Jr. e Reis (2009), que enfatizam, por exemplo, o fato de tratar desiguais de forma igual ao desconsiderar o tamanho do município e sua capacidade orçamentária. Esse fato, na visão dos autores, provoca um engessamento orçamentário de pequenos municípios, acentuando desequilíbrios regionais.

Para Lima (2011) apesar da eficácia da LRF no controle do endividamento, as transferências voluntárias governamentais atuam como força contrária ao desempenho da dívida, pois flexibiliza as restrições orçamentárias constantes da Lei. Essas transferências possuem um lado perverso, pois abrem espaço para comportamentos fiscais irresponsáveis dos administradores estaduais e municipais, produzem efeito expansivo nos gastos (flypaper effect), tendem a estimular a ineficiência de arrecadação e a incentivar o comportamento free-rider por parte dos recebedores, caracterizado pela acomodação do esforço fiscal. (COSSIO, 1998; VELOSO, 2008; CARVALHO; DE OLIVEIRA; CARVALHO, 2009; NASCIMENTO, 2010). Há evidências, inclusive, de que os municípios acabam por criar dependência em relação às transferências governamentais (MASSARDI; ABRANTES, 2016; MORAIS; BONIFÁCIO, 2016) e esse é um fator desfavorável às finanças municipais, repercutindo diretamente no aumento do endividamento.

Portanto, depreende-se, a partir dos diversos estudos que se dedicaram a investigar a influência da LRF sobre as finanças municipais, que os resultados são aparentemente controversos. Embora a Lei tenha sido exitosa em melhorar o resultado primário, conter o crescimento da dívida e controlar a estrutura de capital dos municípios mais endividados, por outro lado, incentivou aumento de gastos de outros municípios, tratou de forma igual municípios diferentes e pode ter acentuado desequilíbrios regionais. Além disso, a Lei pode não ter sido suficiente para conter os impactos de outras medidas com efeitos contrários ao seu propósito principal de melhorar as finanças municipais por meio da sustentabilidade da dívida pública, tais como transferências voluntárias e medidas de afrouxamento fiscal, que parecem 
aliviar a situação dos municípios apenas momentaneamente, sem contudo garantir que possam manter seu endividamento em nível continuamente sustentável, como preconiza a LRF.

\subsubsection{Afrouxamento Fiscal e recessão}

Mesmo com a promulgação da LRF, no início dos anos 2000 o endividamento dos municípios era caracterizado por alta taxa de juros e curto prazo de vencimento dos contratos. As dívidas apresentavam prazo médio de 1,96 ano e encargos de 37,9\% a.a., o que motivou nova renegociação desse passivo pela União em 2001, por meio da Medida Provisória $n^{\circ}$ 2.185/2001, estabelecendo encargos atrelados ao IGP-DI (Índice Geral de Preços Disponibilidade Interna) mais juros de $9 \%$ a.a. (SECRETARIA DO TESOURO NACIONAL, 2016; BRASIL, 2001). Nesse quesito, a MP 2.185/2001 converge à LRF ao estabelecer limitações ao endividamento dos municípios, restringindo a emissão de dívida mobiliária e a contração de novas dívidas se a dívida financeira superar a receita líquida real anual, mas pode ter emitido sinais contrários aos objetivos da LRF ao estabelecer que a União assumisse obrigações de responsabilidade dos municípios.

Porém, em novembro de 2014 foi sancionada a Lei Complementar $\mathrm{n}^{\circ}$ 148, que alterou a LRF e a indexação dos contratos da negociação de 2001 (BRASIL, 2014). Na prática, significou um afrouxamento fiscal, pois os contratos passaram a ser atrelados ao menor índice entre IPCA (Índice Nacional de Preços ao Consumidor Amplo) com juros de 4\% ou taxa SELIC (Sistema Especial de Liquidação e de Custódia). Dessa forma, o montante do endividamento dos municípios foi reduzido em aproximadamente $\mathrm{R} \$ 48$ bilhões, passando de $\mathrm{R} \$ 111,5$ bilhões em dezembro de 2015 para $\mathrm{R} \$ 63,3$ bilhões em março de 2016 (-43\%).

Também em 2014 teve início a mais duradoura recessão brasileira ocorrida no período compreendido por este estudo (dezembro de 2002 e novembro de 2018). De acordo com o CODACE, esse período apresentou quinze trimestres caracterizados como recessão: os dois primeiros trimestres de 2003, o quarto trimestre de 2008, o primeiro trimestre de 2009 e do segundo trimestre de 2014 ao quarto trimestre de 2016. Este último período de recessão, juntamente com o ocorrido entre 1989-1992 foi o mais longo registrado desde 1980, resultando em perda de $8,6 \%$ de PIB. (FGV, 2017).

Espera-se que exista alguma influência desses dois fatos sobre as finanças municipais, pelo potencial de, por um lado amenizar o aperto provocado pelos juros sobre a dívida e, por outro lado, pelas consequências negativas de eventual redução na arrecadação fiscal em decorrência da retração da atividade econômica por um longo período.

A seção seguinte apresenta uma revisão de literatura sobre sustentabilidade da dívida pública e instrumentos econométricos e de diagnóstico de tal condição.

\subsection{Caracterização da condição de sustentabilidade da dívida pública}

Em 1944, Domar iniciou o debate sobre a conceituação de sustentabilidade da dívida pública com a publicação de seu artigo "The burden of debt and national income", o qual, em linhas gerais, analisou algumas regras de crescimento da relação dívida líquida / PIB. A partir daí essa relação passou a ser uma das mais utilizadas para analisar a existência de sustentabilidade da dívida (FONSECA NETO; TEIXEIRA, 2006).

Uma dívida é considerada sustentável, segundo Hamilton e Flavin (1986), se a restrição orçamentária governamental é respeitada intertemporalmente e pode ser liquidada por superávits primários futuros iguais ao valor presente. Foram eles que, de forma pioneira, testaram a sustentabilidade fiscal por meio de teste de estacionariedade do déficit orçamentário para avaliar a sua consistência com a restrição orçamentária temporal. A partir de então, diversos estudos utilizaram testes de raiz unitária e cointegração para avaliar a sustentabilidade 
da dívida pública (HAKKIO; RUSH, 1991; BOHN, 1991; SIMONASSI, 2007; CALDEIRA et al., 2016).

Para manter a dívida constante em relação ao PIB, o que a define como sustentável, o governo municipal precisa gerar resultados positivos, equivalentes à correção da dívida pela taxa de juros, que sejam equivalentes ou superem o impacto da taxa de juros na atualização da dívida (BUITER, 1985; CALDEIRA et al., 2016). A restrição orçamentária intertemporal estabelece que o valor presente dos resultados primários exceda o valor presente dos déficits futuros de maneira a superar a diferença entre a dívida inicial e o valor presente da dívida final. Tal restrição é dada pela Equação 1, onde $r_{t, t+T}$ é o fator que desconta o estoque de dívida e $r_{t, t+j}$ é o fator de desconto do resultado primário entre o período $t$ e $t+j$.

$$
D_{t}=\lim _{t \rightarrow \infty}\left(\frac{D_{t}+T}{r(t, t+T)}\right)-\sum_{i, j=0}^{\infty} \frac{R P_{t+j}}{r(t, t+j)}
$$

Assim, se o lado direito da Equação 1 for igual a zero, há condição suficiente para que seja caracterizada a sustentabilidade da dívida pública, não existindo a situação de "jogo de Ponzi", o que, conforme Giambiagi e Além (2016), ocorre quando o devedor incorre em outra dívida a fim de cumprir o pagamento de juros e principal da dívida já existente.

Para Bohn (1998), a resposta do resultado primário ao aumento da relação dívida líquida/PIB indica de forma confiável a existência ou não de sustentabilidade da dívida. Dessa forma, a relação da dívida sobre o PIB atual depende da diferença corrigida entre esta mesma variável e o resultado primário, ambos no período anterior. Ou seja, existe a necessidade de resultados positivos (superávits) para que haja sustentabilidade. Assim, se a relação dívida líquida/PIB aumenta, os governos podem responder por meio de aumento do resultado primário positivo, de forma a manter esta relação sustentável (CALDEIRA et al., 2016).

A condição de equilíbrio colocada pela restrição intertemporal do governo pressupõe que as despesas governamentais com bens, serviços e juros da dívida ou são supridas pela receita advinda de impostos ou são financiadas por emissão de títulos de dívida pública, de forma que qualquer variação de componentes dentro da restrição não seja afetada pelos preços, ou seja, precisa ser ajustada pela inflação, bem como pelo nível de renda e crescimento econômico, quando ocorrerem (BICALHO; ISSLER, 2011). Portanto, um governo não precisa manter seu orçamento balanceado todo o tempo para ter uma dívida sustentável, mas não pode ter déficits primários persistentes em seu orçamento (MCCALUM, 1984 apud LUPORINI, 2001, p. 70).

Outro debate sobre parâmetros para a sustentabilidade surgiu em 1992, por ocasião do Tratado de Maastricht que objetivava, entre outros aspectos, a unificação monetária da Europa. Para qualificar os países participantes, o Tratado estabeleceu critérios que deveriam ser atendidos, entre eles, a sustentabilidade de suas finanças públicas. Curiosamente, não mencionou o que era considerado como sustentabilidade e apenas fez referência a duas relações que deveriam ser consideradas: 3\% para déficit público sobre o PIB e 60\% para Dívida sobre PIB (PASINETTI, 1998).

Blanchard et al. (1990), afirmaram que existiria sustentabilidade quando a relação dívida pública/PIB retornasse ao seu nível inicial, o que implica na necessidade de superávits primários. Entretanto, Pasinetti (1998) considerou que os autores propunham algo analiticamente complicado e difícil de usar em discussões não estritamente acadêmicas e, por criticar os limites do Tratado de Maastricht, propôs uma inequação para definir algébrica e geometricamente a área da sustentabilidade das finanças públicas, envolvendo três magnitudes: a relação déficit/PIB, dívida/PIB e a taxa de crescimento. Para o autor, existe sustentabilidade da dívida como proporção do PIB quando esta diminui ou se mantém constante no tempo. Assim, o déficit/superávit nominal possa ser expresso pela variação da dívida, que por sua vez 
é resultado da diferença entre receitas e despesas primárias menos a variação do estoque da dívida (de acordo com os juros). Entretanto, tanto o déficit nominal quanto o primário $\left(\mathrm{S}^{\mathrm{P}}\right)$, assim como a dívida (D), também podem ser expressos em termos relativos ao PIB (Y). Neste caso, a sustentabilidade definida em termos do superávit primário obedece a Inequação 2, onde (i) é a taxa de juros e (g) o crescimento do PIB:

$$
\frac{S^{P}}{Y} \geq(i-g) \frac{D}{Y}
$$

Pasinetti (1998) demonstra, portanto, que a sustentabilidade da dívida pública é atingida quando o governo consegue gerar superávit primário que seja igual ou maior que a diferença entre a taxa de juros e o crescimento do PIB multiplicada pela relação entre o estoque da dívida e o PIB.

\section{METODOLOGIA}

Inicialmente serão apresentados dados descritivos da situação fiscal dos municípios no período de vigência da LRF.

Em seguida, calcula-se mês a mês o indicador de sustentabilidade proposto por Pasinetti, para identificar em quais meses a condição de sustentabilidade da dívida pública municipal foi violada. Além disso, com realizou-se regressão tendo esse indicador como variável dependente e uma variável dicotômica, indicativa de recessão como variável explicativa, com o intuito de identificar se há relação entre as duas variáveis.

$\mathrm{Na}$ sequência, baseando-se em Hamilton e Flavin (1986) e estudos posteriores, investigou-se a existência de condição de sustentabilidade da dívida pública municipal agregada, aplicando-se teste estacionariedade e cointegração das séries Resultado Primário e da Dívida Líquida, utilizando dados agregados dos municípios e sempre em proporção ao PIB.

Adicionalmente, no período em que a dívida foi caracterizada como sustentável, foram aplicados testes para avaliar a reação fiscal do resultado primário à dívida liquida por meio de regressão de cointegração e para nova confirmação por meio de teste de estacionariedade dos resíduos.

\subsection{Amostra de dados}

Foram utilizados os dados consolidados pelo $\mathrm{BCB}$ de dívida e resultado primário referente às estatísticas fiscais dos governos municipais, com início em 2001 e frequência mensal, sendo os dados, portanto dados agregados dos municípios. A disponibilidade desses dados motivou a escolha o período, sendo possível utilizar série mais longa, com mais observações e coincidente com os primórdios da criação da LRF. Como os dados foram anualizados, a série tem início em dezembro de 2002.

Para o teste de Pasinetti (1998), os dados utilizados, foram: taxa de juros implícita da dívida municipal (i); PIB acumulado em valores correntes, de onde foi extraída a variação nominal (g); saldo da dívida líquida municipal (D); superávit primário municipal (Sp). Todos os dados estão disponíveis no sítio eletrônico do Banco Central do Brasil.

\subsection{Sustentabilidade de curto prazo}

A sustentabilidade de curto prazo da dívida será testada, utilizando o indicador proposto por Pasinetti (1998), calculado conforme a seguinte inequação:

$$
R P P I B \geq(i-g) \times D L P I B
$$


Onde RPPIB: é o Resultado Primário Municipal Agregado realizado em relação ao Produto Interno Bruto. O resultado primário requerido é dado pelo lado direito da inequação, $(i-g) \times D L P I B$ de Gobetti e Schetitini (2010), $g$, a taxa de crescimento nominal do PIB e DLPIB, a Dívida Líquida Municipal Agregada em relação ao PIB.

\subsection{Sustentabilidade de longo prazo}

Econometricamente, a condição para sustentabilidade da dívida pública pode ser caracterizada pela estacionariedade e por sua cointegração com o resultado primário. Dessa forma, foram realizados testes de raiz unitária pelo método Dickey-Fuller Aumentado para testar a hipótese nula de não-estacionariedade da dívida líquida e do resultado primário municipal sobre o PIB.

A fim de verificar se havia insustentabilidade e a partir de quando essa condição era de longo prazo, a série foi testada inicialmente com o período completo, e depois com redução de um ano por vez até encontrar inversão de diagnóstico. Aí então, as séries foram testadas mensalmente para possibilitar encontrar precisamente o mês a partir do qual a dívida se tornou insustentável. Esse teste foi feito por meio da cointegração de Johansen entre as duas séries a fim de verificar se as séries possuíam ou não relação de longo prazo (GUJARATI; PORTER, 2011).

Uma investigação mais robusta sobre a existência de sustentabilidade de longo prazo foi realizada aplicando-se regressão de cointegração do superávit primário em relação à dívida líquida. Isso é possível sem que o processo do termo de erro seja modelado explicitamente (BOHN, 1998). O procedimento foi realizado seguindo o modelo descrito na Equação 4.

$$
R P P I B_{\mathrm{it}}=\beta_{0}+\beta_{1} D L P I B_{\mathrm{t}-\mathrm{d}}+\mu_{\mathrm{it}}
$$

Onde: $\mathrm{RPPIB}_{\mathrm{t}}$ : é o Resultado Primário Municipal Agregado em relação ao PIB, no período t; DLPIB : Dívida Líquida Municipal Agregada em relação ao PIB, no período t menos d, que é a defasagem a ser definida conforme o critério de seleção VAR; $u_{i t}$ : erro aleatório da regressão.

O número de defasagens do modelo foi definido com base nos seguintes critérios: Teste estatístico LR sequencial modificado (LR), Erro de Predição Final (FPE), Akaike Information Criterion (AIC) e Hannan-Quinn (HQ) e Schwarz Information Criterion (SIC).

Após a realização da regressão de cointegração, foi realizado o teste de raiz unitária dos resíduos a fim de comprovar a estacionariedade, pois conforme sugerido por Trehan e Walsh (1988) é equivalente ao teste de cointegração.

\section{RESULTADOS}

Nesta seção são apresentadas primeiramente, a avaliação descritiva da composição e evolução da dívida líquida municipal. Na sequência são apresentados os resultados dos testes descritos na metodologia para avaliar a existência de sustentabilidade da dívida pública municipal agregada.

\subsection{Evolução da dívida líquida e resultado primário municipais - 2002 a nov/2018}

A dívida líquida do setor público municipal, conforme definição do BCB (2012), corresponde ao saldo líquido do endividamento do setor público não financeiro, sendo 
composta por: (i) dívida mobiliária líquida, que é o total de títulos emitidos pelos respectivos tesouros, menos os títulos em tesouraria; (ii) dívida bancária líquida, que corresponde ao endividamento líquido de aplicações, junto ao sistema financeiro; (iii) dívidas refinanciadas pela União no âmbito da Lei no 8.727/1993; (iv) dívidas estruturadas, decorrentes de operações de créditos assumidas pela União; (v) renegociações, que registram os passivos dos municípios em função da MP 2.185/2001 e (vi) dívida externa líquida, formada pela dívida bruta deduzida das aplicações em moeda estrangeira.

A evolução de cada componente está detalhada na Figura 1, que demonstra o impacto de uma das medidas de socorros aos municípios, a MP 2.185/2001, sendo possível depreender que esta MP é o fator de maior representatividade na composição da dívida dos municípios, alcançando $91 \%$ em maio de 2015 e, após forte redução, chegando a $47 \%$ em novembro de 2018, com simultâneo crescimento da representatividade das dívidas bancárias $(41 \% \mathrm{em}$ novembro de 2018).

Figura 1. Composição da dívida bruta agregada dos municípios (em \%): 2001 a nov/2018

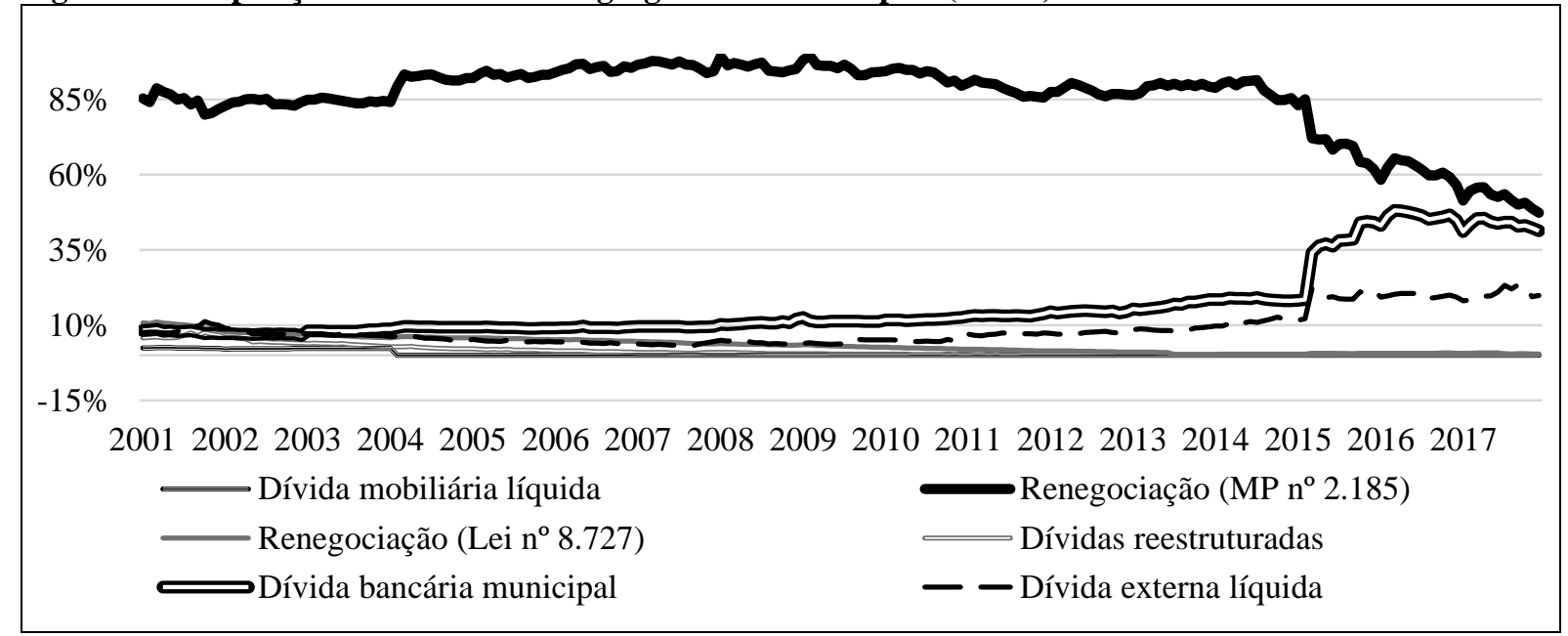

Fonte: dados de "Economia e Finanças: Séries temporais", recuperado de <www.bcb.gov.br>

A Figura 2 apresenta a evolução da dívida municipal em relação ao PIB desde 2002. Observa-se uma expressiva queda em 2016, cuja motivação se deve aos efeitos da LC $\mathrm{n}^{\circ}$ 148/2014. No mesmo gráfico, verifica-se que o déficit primário permanece algum tempo elevado, mesmo após a redução substancial da dívida a partir de março de 2016, recuando nos períodos seguintes

Figura 2. Evolução da dívida líquida municipal (\% PIB) e das necessidades de financiamento do setor público municipal - Déficit Primário (\% PIB): 2001 a nov/2018

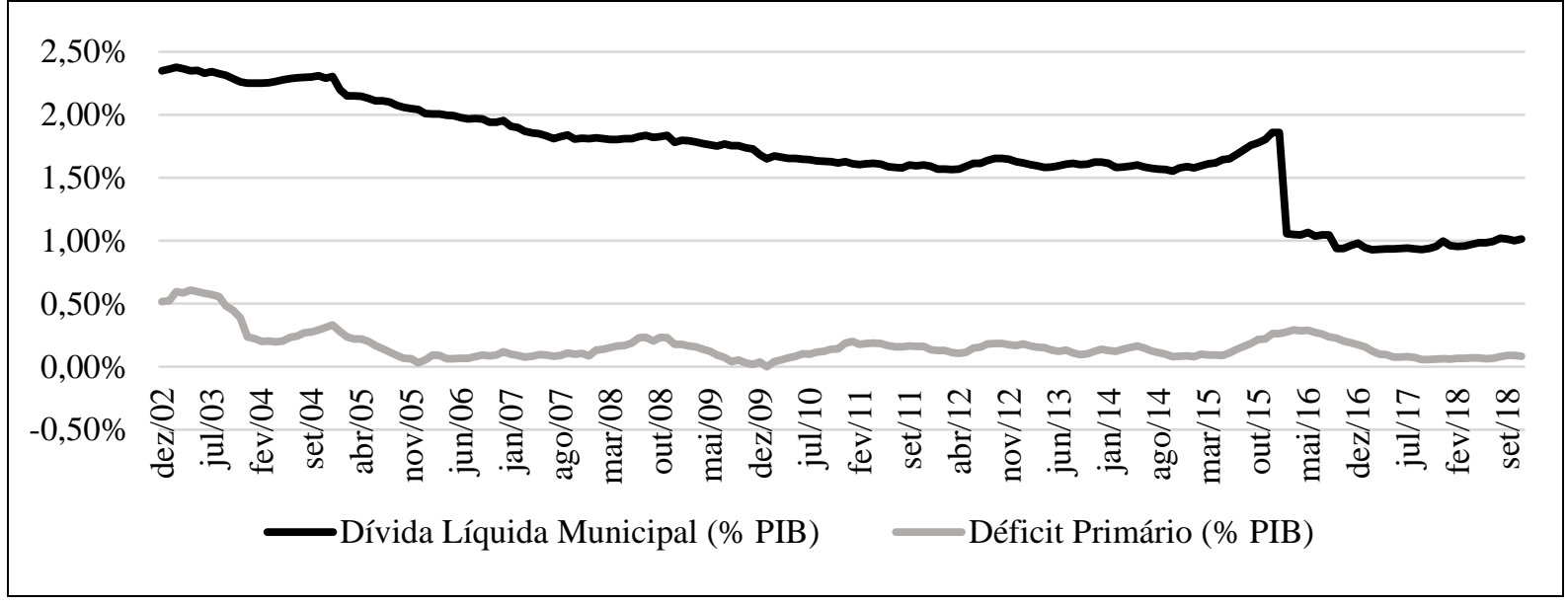


Fonte: dados de "Economia e Finanças: Séries temporais", recuperado de www.bcb.gov.br.

O montante do endividamento dos municípios foi reduzido em aproximadamente $\mathrm{R} \$ 48$ bilhões, passando de $\mathrm{R} \$ 111,5$ bilhões em dezembro de 2015 para $\mathrm{R} \$ 63,3$ bilhões em março de 2016 (-43\%) em função dos efeitos da LC 148/2014. O município de São Paulo foi o maior beneficiário dessa Lei, pois, ao assinar o aditivo contratual em fevereiro de 2016, teve sua dívida reduzida em $\mathrm{R} \$ 46$ bilhões: o saldo devedor passou de $\mathrm{R} \$ 74$ bilhões, em $1^{\circ}$ de janeiro de 2016 , para R\$ 27,5 bilhões (PREFEITURA DE SÃO PAULO, 2016; SECRETARIA DO TESOURO NACIONAL, 2016).

Entretanto, verifica-se que até mesmo antes dessa medida já havia crescimento substancial do déficit primário o qual não foi reduzido imediatamente após a Lei, mas somente após passados alguns meses. A partir desse panorama inicial, a seguir são apresentados os resultados dos testes econométricos e estatísticos.

\subsection{Sustentabilidade de curto prazo: análise do comportamento do resultado primário realizado versus requerido}

Uma análise mês a mês da série completa, por meio do indicador proposto de Pasinetti (1998) para o atendimento da condição de sustentabilidade da dívida, permitiu maior detalhamento do comportamento fiscal dos municípios, ao comparar o resultado primário realizado em relação ao requerido, devendo o primeiro superar o segundo para que se tenha uma situação considerada sustentável.

Verifica-se que, ao longo da série, houve seis períodos onde não foi atendida a condição de sustentabilidade (superávit realizado inferior ao requerido): de dezembro de 2002 a novembro de 2003, de setembro de 2004 a janeiro de 2005 , de junho a novembro de 2008 , de junho de 2012 a abril de 2013, de abril a junho de 2014 e de fevereiro de 2015 até o final da séries (novembro de 2018). Esse último período foi o maior verificado durante toda a série (46 meses) e, em grande parte, coincide com a mais recente recessão vivida pelo Brasil.

Figura 3. Resultado Primário Realizado X Requerido conforme Pasinetti (1998)

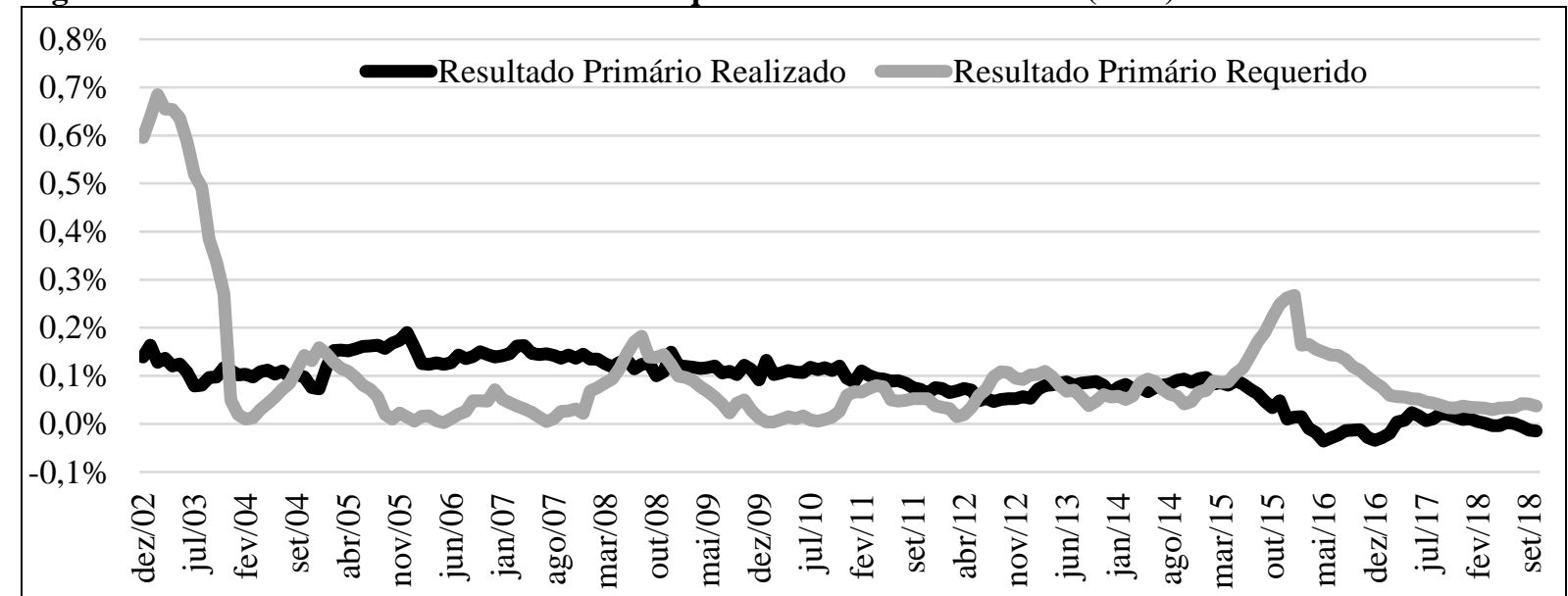

Nota. RPPIB = Resultado Primário Municipal Agregado em relação ao PIB; RPPIB Requerido é dado por (i - g) $\mathrm{x}$ (DLPIB), onde i é a taxa de juros nominal implícita; g, a taxa de crescimento nominal do PIB; DLPIB = Dívida Líquida Municipal Agregada em relação ao PIB.

Fonte: elaborada pelos autores, a partir de teste extraído de Pasinetti (1998)

Assim, foi realizada regressão linear a fim de identificar se a recessão era estatisticamente significante para explicar a sustentabilidade da dívida dos municípios. A hipótese não pode ser rejeitada, pois com $99 \%$ de confiança, a variável recessão é significante para explicar a sustentabilidade dos municípios, e seu efeito é negativamente relacionado. 


\subsection{Sustentabilidade de longo prazo: estacionariedade e cointegração}

Para testar a estacionariedade das séries, ou seja, identificar a presença de raízes unitárias, foram utilizados o teste $\mathrm{ADF}$ sendo que os resultados revelam a hipótese nula de que existe raiz unitária nas duas séries e nos dois períodos não pode ser rejeitada.

Tabela 1. Resultados da regressão linear da sustentabilidade em relação à recessão

\begin{tabular}{cccccc}
\hline \multirow{2}{*}{ Variável } & \multicolumn{5}{c}{$S U S T_{t}=\beta_{0}+\beta_{1} R E C_{t}+\mu_{i t}$} \\
\cline { 2 - 6 } & Coeficiente & Erro Padrão & Estatística t & p-valor & Sig. \\
\hline C & 0,000236 & 0,000082 & 2,894207 & 0,004200 & \\
REC & $-0,001533$ & 0,000271 & $-5,659213$ & 0,000000 & $* * *$ \\
\hline
\end{tabular}

Nota. SUST $_{t}=$ condição de sustentabilidade atendida pela realização de superávit primário superior ao requerido conforme a proposta de Pasinetti (1998); REC: variável dicotômica equivalente a 1 para períodos de recessão e 0 para períodos de expansão econômica; $u_{i t}=$ erro aleatório da regressão. *** Significância dos parâmetros a $99 \%$ Fonte: elaborada pelos autores. Período: dezembro de 2002 a novembro de 2018, dados mensais.

Tabela 2. Teste de raiz unitária: Dickey-Fuller aumentado

\begin{tabular}{ccccccc}
\hline \multirow{2}{*}{$\begin{array}{c}\text { Período } \\
\text { (últimos doze meses) }\end{array}$} & Variável & Estatística $t$ & Probabilidade* & \multicolumn{3}{c}{ Valores Críticos } \\
& & & & $1 \%$ & $5 \%$ & $10 \%$ \\
\multirow{2}{*}{2002 a nov/2018 } & RPPIB & $-1,3433$ & 0,6091 & $-3,4694$ & $-2,8786$ & $-2,5759$ \\
& DLPIB & $-1,0406$ & 0,7384 & $-3,4646$ & $-2,8765$ & $-2,5748$ \\
\hline
\end{tabular}

Nota. RPPIB = Resultado Primário/PIB; DLPIB = Dívida Líquida/PIB. Dados mensais a partir de dez/2002. *Pvalores unilaterais.

Fonte: elaborada pelos autores.

Após a confirmação de que as séries são não estacionárias, foi realizado o teste de cointegração de Johansen, cuja hipótese nula é de não cointegração das séries RPPIB e DLPIB.

Nos períodos testados, os quais se iniciam em dezembro de 2002 e finalizam em novembro de 2018, dezembro de 2017 e dezembro de 2016, os testes indicaram que não poderia ser rejeitada a hipótese de não cointegração das séries, tanto pelo teste do traço ( $\lambda$ traço), quanto pelo teste do máximo autovalor $(\lambda \max )$. A condição para a existência de sustentabilidade é a cointegração, que não houve nesse período. Em função destes resultados os testes foram repetidos mês a mês, de maneira a encontrar evidências de que no mês de março/2016 a condição de insustentabilidade de longo prazo se estabeleceu..

Tabela 3. Teste de cointegração de Johansen

\begin{tabular}{|c|c|c|c|c|c|c|c|}
\hline \multirow{2}{*}{$\begin{array}{c}\text { Período } \\
\text { (últimos doze } \\
\text { meses) }\end{array}$} & \multicolumn{3}{|c|}{ Teste do traço } & \multicolumn{3}{|c|}{ Teste do máximo autovalor } & \multirow{2}{*}{$\begin{array}{c}\text { Diagnóstico quanto à } \\
\text { sustentabilidade }\end{array}$} \\
\hline & $\begin{array}{c}\text { Estatística } \\
\mathrm{t}\end{array}$ & $\begin{array}{l}\text { Valor } \\
\text { crítico } \\
\end{array}$ & Prob. & $\begin{array}{c}\text { Estatística } \\
\mathrm{t}\end{array}$ & $\begin{array}{l}\text { Valor } \\
\text { crítico } \\
\end{array}$ & Prob. & \\
\hline $\mathrm{dez} / 2002$ a dez/2015 & 22,570 & 15,495 & 0,004 & 20,199 & 14,264 & 0,005 & sustentável \\
\hline dez/2002 a mar/2016 & 9,402 & 15,495 & 0,330 & 8,491 & 14,264 & 0,331 & insustentável \\
\hline $\mathrm{dez} / 2002$ a dez/2016 & 7,950 & 15,495 & 0,471 & 7,718 & 14,264 & 0,408 & insustentável \\
\hline dez/2002 a dez/2017 & 8,969 & 15,495 & 0,368 & 8,648 & 14,264 & 0,317 & insustentável \\
\hline dez/2002 a nov/2018 & 9,708 & 15,495 & 0,304 & 9,454 & 14,264 & 0,250 & insustentável \\
\hline
\end{tabular}

Nota. Dados mensais a partir de dez/2002. $\mathrm{N}^{\circ}$ hipotético de relação de cointegração: nenhuma (denota rejeição da hipótese de não cointegração com nível de confiança de 5\%). Teste do traço e do máximo autovalor indicam uma cointegração ao nível de $5 \%$ de confiança.

Fonte: elaborada pelos autores.

Para o período de dezembro de 2002 a dezembro de 2015, a hipótese nula de não cointegração deve ser rejeitada ao nível de $5 \%$. Em outras palavras, há $95 \%$ de probabilidade 
de as séries serem cointegradas, tanto pelo teste do traço ( $\lambda$ traço), quanto pelo teste do máximo autovalor $(\lambda \max )$. Portanto, RPPIB e DLPIB possuem relação de longo prazo, o que denota a existência de sustentabilidade da dívida pública no período entre 2002 e 2015 . A fim de verificar se essa sustentabilidade era consistente, foram realizados mais alguns testes. Primeiramente, uma estimação VAR/MCE permitiu selecionar o número de defasagens a serem consideradas na regressão de reação fiscal. De acordo com os critérios LR sequencial modificado, Erro de Predição Final, informação Akaike e Hannan-Quinn, a defasagem selecionada foi de três períodos, apesar da indicação de um período fornecida pelo teste SIC.

Tabela 4. Critério de ordem de seleção de defasagens VAR: 2002 a 2015

\begin{tabular}{cccccc}
\hline Defasagem & LR & FPE & AIC & SIC & HQ \\
\hline 1 & 1052,848 & $3,71 \mathrm{E}-08$ & $-11,43421$ & $-11.31324^{\mathrm{a}}$ & $-11,38506$ \\
3 & $12.40886^{\mathrm{a}}$ & $3.47 \mathrm{e}-08^{\mathrm{a}}$ & $-11.50060^{\mathrm{a}}$ & $-11,21835$ & $-11.38593^{\mathrm{a}}$ \\
\hline
\end{tabular}

Nota. Variáveis exógenas: RPPIB e DLPIB. LR = teste estatístico LR sequencial modificado; FPE = erro de Predição Final; AIC = Akaike Information Criterion; HQ = Hannan-Quinn; SIC = Schwarz Information Criterion . a Indica a defasagem selecionada por critério.

Fonte: elaborada pelos autores.

Após a seleção da defasagem, a regressão de reação fiscal indicou que a relação entre o superávit primário e a dívida líquida defasada em três períodos é direta, estatisticamente significante e diferente de zero, ou seja, a regressão revela que a dívida pública municipal agregada dos municípios brasileiros foi sustentável no período.

Tabela 5. Resultados da regressão de reação do resultado primário em relação à dívida líquida

\begin{tabular}{cccccc}
\hline \multirow{2}{*}{ Variável } & \multicolumn{5}{c}{$R P P I B_{i t}=\beta_{0}+\beta_{1} D L P I B_{t-3}+\mu_{i t}$} \\
\cline { 2 - 6 } & Coeficiente & Erro Padrão & Estatística t & p-valor & Sig. \\
\hline C & 0,016077 & 0,028887 & 0,556553 & 0,5787 & $* * *$ \\
DLPIB (-3) & 0,046220 & 0,015794 & 2,926517 & 0,0040 & $* * * 20$ \\
\hline
\end{tabular}

Nota. RPPIB $_{i t}=$ Resultado Primário Municipal Agregado em relação ao PIB, no período $t ;$ DLPIB $_{t-1}=$ Dívida Líquida Municipal Agregada em relação ao PIB, no período $t ; u_{i t}=$ erro aleatório da regressão. Período: dezembro de 2002 a dezembro de 2015, dados mensais. *** Significância dos parâmetros a 99\%

Fonte: elaborada pelos autores.

Em complementação, o teste de raiz unitária dos resíduos comprovou a sua estacionariedade, rejeitando a hipótese nula, satisfazendo a condição exigida para a cointegração entre as variáveis RPPIB e DLPIB.

Tabela 6. Estimativas do teste de raiz unitária Dickey-Fuller aumentado dos resíduos

\begin{tabular}{cccccc}
\hline \multicolumn{3}{c}{ Teste Dickey-Fuller Aumentado } & \multicolumn{3}{c}{ Valores Críticos } \\
\hline Período: 2002 a 2015 & Estatística t & Probabilidade* & $1 \%$ & $5 \%$ & $10 \%$ \\
Resíduos & $-4,110395$ & 0,0013 & $-3,474265$ & $-2,880722$ & $-2,577077$ \\
\hline
\end{tabular}

Nota. RPPIB = Resultado Primário/PIB; DLPIB = Dívida Líquida/PIB. *P-valores unilaterais. Dados mensais, a partir de dez/2002.

Fonte: elaborada pelos autores.

\subsection{Análise dos resultados}

O problema de pesquisa procurava esclarecer se houvera sustentabilidade da dívida pública municipal no período de vigência da LRF. Indicador de curto prazo e testes econométricos com séries temporais de longo prazo permitiram responder que sim, mas que essa sustentabilidade não se manteve durante todo o período, havendo alternância ao longo do tempo. Ambos os testes convergiram no diagnóstico quanto a existência de insustentabilidade da dívida nos períodos mais recentes, mas o início desta situação é apontado em momentos 
diferenciados por cada um deles.

Os resultados dos testes evidenciaram que nos anos iniciais da vigência da LRF havia condição insustentável e que, nos anos seguintes houve melhora no resultado primário realizado, o que corrobora estudos sobre o desempenho fiscal de municípios nos períodos anteriores a 2015, como por exemplo: Linhares, Simonassi e Nojosa (2013) que, utilizando modelos vetoriais autorregressivos apontaram sincronismo entre receitas e despesas, com os municípios gerindo melhor suas despesas no período pós-LRF (2001 a 2006); Gadelha (2011) que identificou a influência positiva da LRF sobre o comportamento fiscal dos municípios no período de 1995 a 2009; Jesus Macedo e Corbari (2009) que sugeriram maior efetividade na gestão da dívida após a LRF, no caso de municípios com mais de 100 mil habitantes, investigando de 1996 a 2006; assim como a redução de endividamentos dos municípios do Piauí entre 2001 e 2013 foi identificada por Linhares et al. (2013).

Também houve convergência com os resultados de estudos realizados no âmbito estadual, como os encontrados por Tabosa et al. (2016), que por meio de função resposta verificaram que não há política fiscal ativa dos estados na forma de reação do superávit em razão de aumento da dívida. Os achados deste estudo também corroboram Fontenele et al. (2015), os quais encontraram evidências de insustentabilidade da dívida pública dos estados (exceto-região Centro-oeste) entre 2000 e 2010, por meio de investigação da estacionariedade na relação dívida/PIB.

O indicador de curto prazo de Pasinetti (1998) permitiu avaliar a sustentabilidade mês a mês (com janela móvel de doze meses) e apontou o início de uma persistente condição de insustentabilidade a partir de fevereiro de 2015, que se manteve até novembro de 2018. Além disso revelou que houve momentos de alternância. No período analisado de 192 meses em 83 meses ocorreu situação insustentável da dívida. Esses achados corroboram os de Vazquez (2012) que identificou que comportamentos fiscais divergentes em alguns anos eram compensados por resultados positivos em outros exercícios. Por esse motivo, o autor afirma que a LRF não pode ser tomada como um divisor de águas, mas como um mecanismo facilitador dentro de um processo de regulação que visa garantir equilíbrio fiscal de caráter permanente.

A condição de insustentabilidade de curto prazo parece ter afetado a condição de longo prazo apenas a partir de março de 2016, pois testes de estacionariedade e cointegração indicaram que houve sustentabilidade da dívida pública municipal entre 2002 e 2015. Nesse sentido. De acordo com McCallum (1984, apud LUPORINI, 2001, p. 70), o governo pode enfrentar desbalanceamentos pontuais em seu orçamento ao longo do tempo, entretanto a persistência de déficits é determinante para comprometer a sustentabilidade da dívida, o que vem ocorrendo nos municípios brasileiros, conforme sugerem os resultados dos testes.

Quanto à LC no 148/2014, verifica-se que não teve efeito sobre a sustentabilidade de curto prazo, mas afetou a de longo prazo. Entretanto, ficou evidenciado que essa medida, apesar de garantir algum alívio imediato da situação fiscal não foi suficiente para reverter a trajetória que levaria à insustentabilidade. Isso pode ser explicado pelo fato de não ter havido ajuste nas despesas primárias, que continuaram a pressionar as contas e pelo caráter de rigidez destas.

Em relação à recessão, dado que houve coincidência com o período em que a dívida se mostrou insustentável, uma regressão linear permitiu confirmar a suspeita de que a recessão possuía relação negativa e estatisticamente significante com a sustentabilidade. Novamente, despesas primárias predominantemente rígidas podem não ter permitido adequação do resultado primário em momento de recessão.

Assim, os principais achados desse estudo são: a sustentabilidade de longo prazo da dívida pública municipal foi possível no período de vigência da LRF, mas somente até 2015. No curto prazo, a dívida alternou momentos caracterizados como sustentáveis e insustentáveis, mas a partir de fevereiro de 2015 se manteve nessa segunda condição. Testes de curto e longo prazo apontam momentos diferenciados para o início da condição de insustentabilidade, mas 
convergem a apontar que ela se estabeleceu nos períodos mais recentes.

Assim, verifica-se que a LRF não foi capaz de sozinha garantir sustentabilidade durante todo o período de sua vigência. Apesar de limitar gastos e incentivar a gestão mais eficiente, efeitos de outros fenômenos parecem ter se sobreposto. Tão importante quanto os efeitos imediatos de medidas de afrouxamento fiscal são os sinais de incentivos que emitem. Além disso, ciclos econômicos devem ser considerados na opção por gastos rígidos ou flexíveis. Tais conclusões se alinham às de Gerick e Clemente (2011), para os quais a LRF torna mais importante o papel do gestor e faz aumentar significativamente a importância da poupança de receitas correntes na determinação do montante de recursos sobre os quais os gestores podem exercer as suas escolhas.

\section{CONSIDERAÇÕES FINAIS}

O objetivo deste estudo foi analisar o comportamento da dívida pública municipal quanto à sua sustentabilidade no período de 2002 a 2018. Para tanto, a partir de dados agregados dos municípios disponibilizados pelo $\mathrm{BCB}$ relativos à dívida e ao superávit primário, foram utilizados testes de cointegração, estacionariedade e regressão de reação do superávit à dívida, para diagnóstico de longo prazo e um indicador de curto prazo, proposto por Pasinetti (1998), para uma avaliação da evolução mensal. Além disso, a pesquisa analisou os efeitos sobre a sustentabilidade de dois fatos ocorridos no intervalo estudado: o afrouxamento fiscal concedido pela LC $\mathrm{n}^{\circ} 148 / 14$ e a recessão econômica que se instalou entre abril de 2014 e dezembro de 2016.

Os principais achados permitiram inferir que a condição de sustentabilidade de longo prazo da dívida pública municipal foi atendida no período de vigência da LRF, mas somente até 2015. Indicador de curto prazo revelou que a dívida alternou momentos caracterizados como sustentáveis e insustentáveis entre 2002 e 2018, mas a partir de fevereiro de 2015 se manteve persistentemente como insustentável. Os testes econométricos identificaram que a condição de sustentabilidade foi violada a partir de março de 2016 até o final do período analisado (novembro de 2018). Sendo assim, os testes de curto e longo prazo apontaram momentos diferentes para a perda de sustentabilidade, mas convergiram no diagnóstico de persistência nos da condição de insustentabilidade nos períodos mais recentes. Assim, foi possível verificar que a condição de sustentabilidade de curto prazo pode até ser violada por alguns períodos, mas é necessária persistência desta condição para que se instale situação insustentável no longo prazo.

Além disso, foi possível verificar que a medida de afrouxamento fiscal promovida pela LC 148/2014, embora tenha aliviado as finanças municipais, não foi suficiente para garantir a sustentabilidade da evolução da dívida nos momentos seguintes. Da mesma forma, o estudo forneceu indícios de que recessão econômica influencia negativamente a sustentabilidade da dívida.

Percebe-se que embora a LRF tenha contribuído para a redução de endividamento e contenção de gastos como apontado pela literatura, ela pode não conseguir neutralizar influências que outros fenômenos, políticos ou econômicos, por exemplo, podem ter sobre o endividamento. Por outro lado, medidas de afrouxamento fiscal que reduzem endividamento principal ou juros podem ser inócuas se não incentivarem a redução de despesas primárias ou o aumento de receitas. Além disso, se em momento de recessão, não houver concomitante adequação do resultado primário, em função da rigidez dos gastos, por exemplo, a deterioração fiscal impactará a sustentabilidade. Algum tipo de consideração do efeito dos ciclos econômicos e formas de neutralizá-los precisam ser desenvolvidas e aplicadas pelos municípios.

O estudo contribui para o debate a respeito do alcance e efetividade dos limites de gastos e endividamento pretendidos pela LRF e sua relação com a sustentabilidade da dívida pública municipal. Em parte, o estudo corrobora a literatura anterior, ao encontrar evidências dos efeitos favoráveis da LRF sobre o endividamento municipal nos períodos iniciais de sua vigência. 
Além disso, contribui ao demonstrar como testes de longo e curto prazo podem apontar sustentabilidade em momentos diferentes no curto prazo, mas convergir no longo prazo. Outra contribuição diz respeito ao debate sobre a eficácia e possível influência de medidas de renegociação de dívida e de socorro a entes subnacionais sobre os objetivos da LRF. Além disso, a discussão trazida neste artigo pode auxiliar a literatura sobre sinais e incentivos que esses e outros atos governamentais podem fornecer ao comportamento fiscal de entes federados. Adicionalmente, ao fornecer indícios sobre o efeito de ciclos econômicos sobre a sustentabilidade, o estudo contribui com o debate sobre a possível necessidade de medidas de ajustamento financeiro dos municípios em função de diferentes cenários macroeconômicos.

Como recomendação de estudos posteriores, sugere-se o aprofundamento das pesquisas no sentido de elucidar os determinantes primários da piora da condição fiscal dos municípios nos períodos recentes. Ressalte-se que os achados desse estudo se referem ao conjunto dos governos municipais, portanto, não se aplicam para casos individuais assim como são influenciados pela relevância de determinados municípios na composição das variáveis estudadas.

\section{REFERÊNCIAS}

ARAÚJO, A. H. S.; SANTOS FILHO, J. E. dos; GOMES, F. G. Lei de Responsabilidade Fiscal: efeitos e consequências sobre os municípios alagoanos no período 2000-10. Revista de Administração Pública, Rio de Janeiro, v. 49, n. 3, p. 739-759, 2015.

BANCO CENTRAL DO BRASIL. Manual de estatísticas fiscais publicadas pelo departamento econômico do Banco Central do Brasil. Brasília, DF, 2012.. Disponível em: <http://www.bcb.gov.br/ftp/infecon/Estatisticasfiscais.pdf >

BANCO CENTRAL DO BRASIL. Relatório de Inflação. Brasília, DF, 2016. Disponível em: 〈http://www.bcb.gov.br/htms/relinf/port/2016/09/ri201609P.pdf>

BANCO CENTRAL DO BRASIL. Economia e finanças: séries temporais. Disponível em: <http://www.bcb.gov.br/?serietemp >. Acesso em jan. 2019.

BICALHO, A.; ISSLER, J. V. Teste de sustentabilidade da dívida, ajuste fiscal no Brasil e consequências para o produto. In: BACHA, E. L.; BOLLE, M. B. Novos dilemas da política econômica: ensaios em homenagem a Dionísio Dias Carneiro. Rio de Janeiro: LTC, 2011. p. 258-272.

BLANCHARD, O. J.; CHOURAQUI, J. C.; HAGEMANN, R.; SARTOR, N. (1990). The sustainability of fiscal policy: New answers to an old question. OECD Economic Studies, v. 15, 1990. p. 7-35.

BOHN, H. Budget balance through revenue or spending adjustments? Some historical evidence for the United States. Journal of monetary economics, v. 27, n. 3, p. 333-359. 1991.

BOHN, H. The behavior of US public debt and deficits. The Quarterly Journal of economics, v. 113, n. 3, p. 949-963. 1998.

BRASIL. Constituição (1988). Constituição da República Federativa do Brasil de 1988.

Disponível em: <http://www.planalto.gov.br/ccivil_03/constituicao/constituicao.htm> 
BRASIL. Lei Complementar $\mathbf{n}^{\mathbf{0}}$ 101, de 4 de maio de 2000. Estabelece normas de finanças públicas voltadas para a responsabilidade na gestão físcal e dá outras providências. Disponível em: <http://www.planalto.gov.br/ccivil_03/leis/LCP/Lcp101.htm>

BRASIL. Lei Complementar $\mathbf{n}^{\mathbf{0}} \mathbf{1 4 8}$, de 25 de novembro de 2014. Altera a Lei Complementar $n^{\circ} 101$, de 4 de maio de 2000, que estabelece normas de finanças públicas voltadas para a responsabilidade na gestão fiscal; dispõe sobre critérios de indexação dos contratos de refinanciamento da dívida celebrados entre a União, Estados, o Distrito Federal e Municípios; e dá outras providências. Disponível em: <http://www.planalto.gov.br/ccivil_03/leis/LCP/Lcp148.htm>

BRASIL. Lei no 7.614, de 14 de julho de 1987. Autoriza a realização, em caráter extraordinário, de operações de crédito à conta e risco do Tesouro Nacional, e dá outras providências. Disponível em: <http://www.planalto.gov.br/ccivil_03/leis/19801988/L7614.htm>

BRASIL. Lei $\mathbf{n}^{\mathbf{0}}$ 7.976, de 27 de dezembro de 1989. Dispõe sobre o refinanciamento pela União da dívida externa de responsabilidade dos Estados, do Distrito Federal e dos Municípios, inclusive suas entidades da Administração Indireta, e dá outras providências. Disponível em: <http://www.planalto.gov.br/ccivil_03/leis/L7976.htm>

BRASIL. Lei $\mathbf{n}^{\mathbf{0}} \mathbf{8 . 7 2 7}$, de 5 de novembro de 1993. Estabelece diretrizes para a consolidação e o reescalonamento, pela União, de dívidas internas das administrações direta e indireta dos Estados, do Distrito Federal e dos Municípios, e dá outras providências. Disponível em: <http://www.planalto.gov.br/ccivil_03/leis/L8727.htm>

BRASIL. Medida Provisória no 2.185, de 24 de agosto de 2001. Estabelece critérios para a consolidação, a assunção e o refinanciamento, pela União, da dívida pública mobiliária e outras que especifica, de responsabilidade dos Municípios. Disponível em: <http://www.planalto.gov.br/ccivil_03/mpv/2185-35.htm>

BUITER, W. H. A guide to public sector debt and deficits. Economic policy, v. 1, n. 1, p. 13-61. 1985.

CALDEIRA, A. A.; WILBERT, M. D.; MOREIRA, T. B. S.; SERRANO, A. L. M. Brazilian State debt sustainability: an analysis of net debt and primary balance. Revista de Administração Pública, Rio de Janeiro, v. 50, n. 2, p. 285-306. 2016.

CARVALHO, D. F.; DE OLIVEIRA, C. C. R.; CARVALHO, A. C. Desigualdades econômicas inter-regionais, capacidade tributária e esforço fiscal dos estados da Amazônia (1970-2000): uma abordagem econométrica de fronteira estocástica. Novos Cadernos NAEA, Belém, PA, v. 10, n. 2, p. 5-48. 2009.

CONFEDERAÇÃO NACIONAL DOS MUNICÍPIOS [CNM]. Municípios enfrentam dificuldades para cumprir limites de gasto com pessoal. Boletim CNM. Brasília, DF. jul. 2016. Disponível em: http://www.cnm.org.br/portal/dmdocuments/Boletim_Julho_2016.pdf

COSSÍO, F. A. B. Disparidades econômicas inter-regionais, capacidade de recursos tributários, esforço fiscal e gasto público no federalismo brasileiro. 1998. $131 \mathrm{f}$. Dissertação de Mestrado em Economia, Pontifícia Universidade Católica do Rio de Janeiro, Rio de Janeiro, RJ, Brasil. 21 Prêmio BNDES de Economia. 1998. 
COSTA, C. E. E. L. da. Sustentabilidade da dívida pública. In: SILVA, A. C.; CARVALHO, L. O. de; MEDEIROS, O. L. de (organizadores). Dívida Pública: a experiência brasileira. Secretaria do Tesouro Nacional - Banco Mundial, Brasília. 2009. p. 81-99.

COSTA, J. F. DA. Reflexos da Lei de Responsabilidade Fiscal no endividamento dos municípios brasileiros. In: Congresso Brasileiro de Contabilidade, 18, 2008, Gramado, RS, Brasil. Anais... Brasília: Conselho Federal de Contabilidade, 2008. Disponível em: < http://www.congressocfc.org.br/hotsite/trabalhos_1/334.pdf>

FONTENELE, Ana Lúcia; TABOSA, F. J. S.; OLIVEIRA JUNIOR, J.N.; GUIMARÃES, D. B. Sustentabilidade da dívida pública dos estados brasileiros. Revista Ciências Administrativas, v. 21, n. 2, 2015.

FIORAVANTE, D. G.; PINHEIRO, M. M. S.; VIEIRA, R. D. S. Lei de responsabilidade fiscal e finanças públicas municipais: impactos sobre despesas com pessoal e endividamento. Brasília, DF: IPEA, 2006. 31 p. (Texto para Discussão, n. 1223).

FUNDAÇÃO GETÚllo VARGAS (FGV). Comitê de Datação de Ciclos Econômicos: Comunicado de início de recessão. Ago. 2015. Disponível em:

$<$ https://portalibre.fgv.br/estudos-e-pesquisas/codace>

FUNDAÇÃo GeTÚlio VARGAS (FGV). Comitê de Datação de Ciclos Econômicos: Comunicado de datação de ciclos mensais brasileiros. Out. 2017. Disponível em: < https://portalibre.fgv.br/estudos-e-pesquisas/codace>

GADELHA, S. R. D. B. Análise dos impactos da Lei de Responsabilidade Fiscal sobre a despesa de pessoal e a receita tributária nos municípios brasileiros: um estudo com modelo probit aplicado a dados em painel. Revista Brasileira de Economia de Empresas, Brasília, DF, v. 11, n. 1, p. 65-77. 2011.

GERIGK, Willson; CLEMENTE, Ademir. Influência da LRF sobre a gestão financeira: espaço de manobra dos municípios paranaenses extremamente pequenos. Revista de Administração Contemporânea, v. 15, n. 3, p. 513-537, 2011.

GIAMBIAGI, F.; DE ALÉM, A. C. D. Finanças públicas: teoria e prática no Brasil. 5. ed. Rio de Janeiro: Elsevier Brasil. 2016.

GOBETTI, S. W.; SCHETTINI, B. P. Dívida Líquida e Dívida Bruta: uma abordagem integrada para analisar a trajetória e o custo do endividamento brasileiro. Brasília, DF: IPEA, 2010. 76 p. (Texto para Discussão, n. 1514).

GUJARATI, D. N.; PORTER, D. C. Econometria Básica. 5. ed. Porto Alegre: AMGH Editora Ltda. 2011.

HAKKIO, C. S.; RUSH, M. Is the budget deficit "too large?" Economic inquiry, v. 29, n. 3, p. 429-445. 1991.

HAMILTON, J. D.; FLAVIN, M. On the limitations of government borrowing: A framework for empirical testing. American Economic Review, v. 76, n. 4, p. 808-819. 1986. Disponível em: <http://ideas.repec.org/a/aea/aecrev/v76y1986i4p808-19.html> 
Vanessa R. dos Santos Cardoso - Daniel A. Pansani - André Luiz M. Serrano - Marcelo D. Wilbert

INTERNATIONAL MONETARY FUND (IMF). Fiscal Monitor: Debt - Use It Wisely. Washington. Out. 2016. Disponível em:

https://www.imf.org/external/pubs/ft/fm/2016/02/pdf/fm1602.pdf

JESUS MACEDO, J. de; CORBARI, E. C. Efeitos da lei de responsabilidade fiscal no endividamento dos municípios brasileiros: uma análise de dados em painéis. Revista Contabilidade \& Finanças, São Paulo, v. 20, n. 51, p. 44-60. 2009.

LIMA, S. C. Desempenho fiscal da dívida dos grandes municípios brasileiros. 2011. Tese (Doutorado em Controladoria e Contabilidade: Contabilidade) - Faculdade de Economia, Administração e Contabilidade, Universidade de São Paulo, São Paulo, 2011.

LINHARES, F.; PENNA, C.; BORGES, G. Os efeitos da Lei de Responsabilidade Fiscal no endividamento dos municípios do Piaú. Revista de Administração Pública, Rio de Janeiro, v. 47, n. 6, p. 1359-1374. 2013.

LINHARES, F. C.; SIMONASSI, A. G.; NOJOSA, G. M. A dinâmica do equilíbrio financeiro municipal e a Lei de Responsabilidade Fiscal. Economia, v. 13, n. 3b, p. 735-758, 2012.

LOPREATO, F. L. C. O endividamento dos governos estaduais nos anos 90. Economia e Sociedade, Campinas, SP, v. 9, n. 2, p. 117-158. 2016.

LUPORINI, V. A sustentabilidade da dívida mobiliária federal brasileira: uma investigação adicional. Análise Econômica, Porto Alegre, RS, v. 19, n. 36, p. 69-84. 2001.

MASSARDI, W. D. O.; ABRANTES, L. A. Dependência dos municípios de Minas Gerais em relação ao FPM. Revista de Gestão, Finanças e Contabilidade, Senhor do Bonfim, BA, v. 1 , n. 6 , p. 173-187. 2016.

MATIAS-PEREIRA, J. Finanças públicas: foco na política fisscal, no planejamento e orçamento público. 6. ed. São Paulo: Atlas. 2012.

MELLO, G. R. de; DALCHIAVON, E. C. A lei de responsabilidade fiscal (LRF) e o impacto sobre o endividamento dos municípios potiguares. Contextus, Fortaleza, CE, v. 10, n. 2, p. 48-60. 2012.

MORAIS, H. A. R. de; BONIFÁCIO, J. N. S. Transferências constitucionais: uma análise da representatividade do Fundo de Participação dos Municípios para a região do Alto Oeste Potiguar. Tekhne e Logos, Botucatu, SP, v. 7, n. 2, p. 16-32. 2016.

NASCIMENTO, E. R.; DEBUS, I. Lei complementar $\mathbf{n}^{\mathbf{0}}$ 101/2000: entendendo a lei de responsabilidade fiscal. Secretaria do Tesouro Nacional. 2002.

NASCIMENTO, J. D. S. Efeitos das transferências financeiras sobre os gastos e a arrecadação dos municípios brasileiros. 2010. Tese de Doutorado em Economia, Universidade Federal de Viçosa, Viçosa, MG, Brasil.

NETO, F. D. A. F.; TEIXEIRA, J. R. Sustentabilidade da Dívida Pública no Brasil.

Economia, Brasília, DF, v. 7, n. 1, p. 101-132. 2006. 
PASINETTI, L. L. The myth (or folly) of the 3\% deficit/GDP Maastricht 'parameter'. Cambridge Journal of Economics, v. 22, n. 1, p. 103-116. 1998.

PINTO, D. S.; COSTA, A. D. J. B.; WILBERT, M. D. Endividamento dos estados brasileiros: Análise das Sanções e Restrições da Lei de Responsabilidade Fiscal. Gestão \& Sociedade:

Revista de Pós-Graduação da Uniabeu, Belford Roxo, RJ, v. 4, n. 1, p. 1-17. 2015.

PINTO, N. G. M.; CORONEL, D. A.; VIEIRA, K. M.; CERETTA, P. S. A influência dos fatores socioeconômicos no endividamento dos municípios do Rio Grande do Sul. Revista Brasileira de Gestão e Desenvolvimento Regional, Taubaté, SP, v. 11, n. 1, p. 393-419. 2015.

PREFEITURA DE SÃO PAULO. Prefeitura assina acordo de renegociação da dívida do Munícipio com a União. Disponível em: <http:// http://capital.sp.gov.br/noticia/prefeituraassina-acordo-de-renegociacao-da-divida>. Acesso em 25 out. 2016.

SANTOLIN, R., JAYME JR, F. G.; REIS, J. C. dos. Lei de Responsabilidade Fiscal e implicações na despesa de pessoal e de investimento nos municípios mineiros: um estudo com dados em painel dinâmico. Estudos Econômicos, São Paulo, v. 39, n. 4, p. 895-923. 2009.

SECRETARIA DO TESOURO NACIONAL. Boletim de Finanças Públicas dos Entes Subnacionais. Disponível em: <https://www.tesouro.fazenda.gov.br/-/stn-divulga-novoboletim-de-financas-de-estados-e-municipios>. Acesso em: 25 out. 2016.

SIMONASSI, A. G.; ARRAES, R. Função de resposta fiscal, múltiplas quebras estruturais e a sustentabilidade da dívida pública no Brasil. In: Encontro Nacional de Economia da ANPEC, 35., 2007, Recife, PE, Brasil. Anais... ANPEC, 2007.

TABOSA, Francisco José Silva; FERREIRA, Roberto Tatiwa; SIMONASSI, Andrei Gomes; KHAN, Ahmad Saeed; TOMAZ, Daniel. Reação fiscal ao aumento da dívida pública: uma análise para os estados brasileiros. Economia Aplicada, v. 20, n. 1, p. 57-71, 2016.

TREHAN, B.; WALSH, C. E. Common trends, the government's budget constraint, and revenue smoothing. Journal of Economic Dynamics and Control, v. 12, n. 2-3, p. 425-444. 1988.

VAZQUEZ, Daniel Arias. Os efeitos da Lei de Responsabilidade Fiscal sobre as finanças municipais: divisor d'água ou a consolidação de um processo? Temas de Administração Pública, v. 4, n. 7, 2012.

VELOSO, J. F. A. As transferências intergovernamentais e o esforço tributário municipal: uma análise do Fundo de Participação dos Municípios (FPM). 2008. 113 f. Dissertação de Mestrado em Economia de Empresas, Universidade Católica de Brasília, Brasília, DF, Brasil. 2008. 